\title{
HARMONIZATION OF EUROPEAN LEGISLATION IN THE FIELD OF SAFETY AND HEALTH AT WORK IN THE LEGAL SYSTEM OF THE REPUBLIC OF NORTH MACEDONIA
}

\author{
Andon Majhoshev ${ }^{1}$, Kristijan Jovanov ${ }^{2}$ \\ 1,2 Faculty of Law at the University "Goce Delchev" - Shtip, North Macedonia \\ andon.majhosev@ugd.edu.mk, kristijan.072096@student.ugd.edu.mk
}

\section{Professional Paper \\ 10.5937/jouproman9-31909}

\begin{abstract}
Occupational safety and health is one of the most important international labor standards of ILO. This means that ILO member states should ensure encouraging and maintenance at the highest level of safe working conditions in order to avoid accidents and occupational diseases. Achieving this goal means that employers must make a continuous risk assessment at the workplace, and at the same time decide whether appropriate measures and activities are necessary in order to create the highest level of safety and health at work, i.e. to avoid side effects. In order to achieve this goal, a systematic approach is necessary in preventive action and connection of all entities that are bearers of certain obligations and activities at the national level, but also beyond the international institutions in this area.
\end{abstract}

By application for membership of the Republic of Macedonia in the European Union on 22 of March 2004, the process of harmonization of the domestic with the European labor legislation begins, and thus inevitably harmonization of the domestic legislation for safety and health at work with the European. Thereby, this process takes place pursuant to article 32 of the Constitution of the Republic of Macedonia, according to which the protection of workers is of primary importance, i.e. health and safety at work is a constitutional-legal category and every individual has the right to work, free choice of employment and work protection.

In the harmonization process the basic concept is the Framework Directive 389/391/EES for safety and health at work, according to which the national legislation on safety and health at work should be harmonized exactly according to the principles of this directive.
Key words: work safety and health, employer, employee, harmonization, directive.

\section{Introduction}

Approaching the national legislation to the law of the European Union in the process of European integration is an inevitable step for each country that wants full membership. One of the Copenhagen criteria $^{1}$ that the Republic of Macedonia needs to meet is precisely harmonization of its national legislation with the acquis commmunautarieie $^{2}$ with the law of the European Union.

The term harmonization, i.e. approximation can be defined as adoption of the European law and mutual harmonization of the legislation of the EU member states, i.e. harmonization of the law of the candidate or aspirant countries for membership with the EU law and the legislations of the member states and their incorporation into the national law with a special procedure and methods of harmonization ${ }^{3}$.

\footnotetext{
${ }^{1}$ Harmonization. Last time approached on 01.12.2020. https://ec.europa.eu/neighbourhoodenlargement/policy/conditions-membership_en

${ }^{2}$ This term refers to the primary (founding contracts) and secondary law (legal acts created by the institutions) of the EU, the decisions of the European Court of Justice. It is about 52,000 legal acts that regulate the overall social life, a number that is constantly increasing.

${ }^{3}$ Methods of harmonization of national legislation with the law of the European Union (2008). Book 2, - Macedonian Academy of Sciences and Arts, Skopje, 12.
} 
The methodological significance of the harmonization refers to the EU legal regulations with which the domestic legislation should be harmonized, i.e. the harmonization establishes a goal towards achieving internal unity and avoiding internal conflicts between the different parts of the legal systems that aim at eliminating internal contradictions and differences between national legislations based on commonly defined standards ${ }^{4}$.

For transition countries, aspirants or candidates such as the Republic of Macedonia, the harmonization of legal systems is a process that should establish a reform of legal systems followed by radical political, economic and social changes, which mean abandoning the former basic principles and setting a new legal framework for the transition to democracy, the rule of law, human rights and freedoms and market democracy.

By ratification of the Republic of Macedonia of the Stabilization and Association Convention in the $\mathrm{EU}^{5}$ in 2001, our country committed to harmonization of the legal system with the one in the EU, where among other things it was emphasized that one of the top priorities will be meeting the Copenhagen criteria defined from the European Council since 1993. The harmonization process is defined in Chapter VI, article 68 paragraph 1 which states: "The Parties recognize the importance of adapting the existing and future laws of the Republic of Macedonia to those of the Community. The Republic of Macedonia shall strive to gradually ensure compatibility of its laws with those of the Community. By receiving the candidate status on December 17, 2005 the

${ }^{4}$ Ibidem page 13

${ }^{5}$ Decree on promulgation of the law on ratification of the Stabilization and Association Settlement of the Republic of Macedonia and the European Communities and its member states - 12.04.2001
Republic of Macedonia, the obligation for harmonization of the legal system is raised to the level of a specific obligation for harmonization of domestic law in 33 areas, determined by the so-called "White Paper" according to which the harmonization process of legal acts can be divided into three stages:

1. Transposition of the legal measures of the Community into national legislation;

2. Implementation of the measures into state institutions;

3. Implementation of harmonized national acts. ${ }^{6}$

For that purpose, the Republic of Macedonia prepares a National Program for Adoption of the Approximation of EU Legislation (NPAA) ${ }^{7}$, where are listed all legal and bylaw acts that need to be adjusted, i.e. harmonized with EU legal acts.

\section{International Occupational Safety and Health Regulations}

Several international organizations and institutions such as ILO, the UN, the Council of Europe and the EU pay respectable attention to occupational safety and health as evidenced by the adoption of several Charters, Conventions, Recommendations, Declarations, etc. in this area. These international legal instruments represent wider legal framework and oblige member states to implement into the national legislations.

\footnotetext{
${ }^{6}$ White paper on the preparation of the Associated Countries of Central and Eastern Europe for Integration into the Internal Market of the Union.COM (95) 163 final. Executives summary Vol. I page 3-6.

${ }^{7}$ National Program for Adoption of the Approximation of EU Legislation last accessed on 01.12.2020. https://www.mtsp.gov.mk/nacionalna-programa-za-usvojuvanjena-pravoto-na-eu-npaa.nspx, .
} 


\subsection{Occupational safety and health in UN acts}

The Constitution of ILO (International Labor Organization), adopted in 1919, establishes the basic goals of ILO, which are expressed in article 427 of the Treaty of Versailles of 1919, which are implemented in the ILO Constitution. According the Preamble of the ILO Constitution, ILO objectives can be divided into three main groups. One of them refers to the working conditions where it is said that "poor working conditions bring injustice, misery and poverty to a large number of people, which results in great dissatisfaction that threatens world peace and harmony." These goals are also conveyed in the Philadelphia Declaration of June 10, 1944, where in Chapter III, as one of the main goals of ILO is stated "achieving adequate protection of life and health of employees in all occupations." 9

The Universal Declaration of Human Rights, adopted by Resolution 217A (xxx) of 10 December 1948 by the UN General Assembly, also explicitly emphasizes the right of each employee to "fair and satisfactory working conditions and protection against unemployment". ${ }^{10}$

The UN International Covenant on economic, social and cultural rights obliges the contracting states to take maximum steps in order respect the economic, social and cultural rights of each citizen, where the right of everyone to enjoy fair and favorable working conditions, which provide "safety and hygienic working conditions" is very important. ${ }^{11}$. We have previously mentioned that all international organizations and institutions have implemented this goal by

\footnotetext{
${ }^{8}$ Dr. B Bukuljash and m-r Adrijana Bilikj, Меѓународно радно право со посебним освртом на МОР, Сплит, 2006 page29. ${ }^{9}$ Philadelphian declaration, Chapter 3 , st. g.

${ }^{10}$ See article 23 paragraph 1 of the UN Universal declaration of human rights

${ }^{11}$ See article 7 of the UN International pact for economic, social and cultural rights.
}

adopting several Charters, Conventions, Recommendations, Directives and others.

\subsection{Occupational safety and health in ILO acts}

Although ILO is an integral part of the UN, i.e. it represents specialized UN agency, we still believe that the acts (Conventions and Recommendations) adopted by this organization should be separated in a special segment due to their tangibility, specificity and specialty. As more important ILO Conventions related to safety and health at work we would mention the following: Convention No. 16 on medical examination of young people; Convention no. 17 for compensation of employees in case of work injury; Convention no. 18 for compensation of employees (disease in the workplace); Convention no. 24 for sickness insurance (in industry); Convention no. 25 for insurance in case of illness (in agriculture); Convention no. 32 for accident protection; Convention no. 81 for labor inspection; Convention No. 102 on Social Security; Convention no. 121 for benefits due to injury at work; Convention no. 148 for working environment (air pollution, noise, vibration); Convention no. 155 for safety and health at work; Convention no. 161 for services for protection of health at work, and others.

Of all the above conventions, we would single out the International Convention no. 155 of the ILO on Occupational Safety and Health adopted at the $67^{\text {th }}$ session of the ILO General Assembly on 22 of June 1981, and entered on 11.08.1983. This convention was ratified by the Parliament of the RM in 1991, which means that the provisions of the convention are part of our labor legislation. Specific implementation of the provisions of the mentioned Convention are significant part of the provisions of this Convention are implemented in the Law on Safety and Health at Work (Official Gazette of RM no. 92/07). 
According to Article 4 of the Convention, each member, based on national conditions and practices, and in consultation with the major part of the representatives of (representative) organizations of employers and employees, should formulate, implement and periodically review a coherent national safety and health policy. ${ }^{12}$ This means that every ILO member state that has ratified this convention should adopt a National Safety and Health Policy (Program). In this context, the main goal of such a policy should be protection against accidents and injuries of health whose occurrence is related to the workplace, by reducing the risks associated with the work environment within reasonable limits. ${ }^{13}$

2.3 Regulation on safety and health at work in the acts of the Council of Europe and the EU

Occupational safety and health, as one of the international labor standards, in addition to having an important place in the international legal instruments of the $\mathrm{UN}$, it has also provided its place in the acts of all major regional organizations, especially the European Union. The most important EU acts relevant to occupational safety and health are the Single European Act of 1986, the European Social Charter of the Council of Europe of 1961.

\section{The European Social Charter was} adopted on 18 October 1961 by the Council of Europe and entered in 1965. The Charter was revised twice in 1988 and 1996, in which the contracting parties as goal to their policy aim to "implement the principle that all employees have the right to safe and sound working conditions (Part 1, item 3). Part 2 of the Charter in article 3 states that in order to ensure the effective exercise of the right to safe and sound working conditions, the contractual

\footnotetext{
${ }^{12}$ Article 4 paragraph 1 of the Convention no.155 of ILO that refers to the safety and health of employees

${ }^{1313}$ Ibid. article 4 paragraph 2
}

parties obliged, in consultation with the organizations of employers and employees, to:

formulate, implement and periodically monitor the single national policy on occupational safety and health and the work environment. The primary purpose of this policy is to improve occupational safety and health and to prevent injuries that may occur at work and related to work, especially by reducing the causes and risks that inevitably occur in working environment.

1. to adopt safety and health regulations;

2. to ensure application of such regulations by appropriate supervision measures and

3. to promote the development of the occupational health service for all employees who would have primarily preventive and advisory functions.

The Contract for foundation of the European Union, in Chapter XI, Part 1, that refers to the provisions on social issues, namely articles 136 and 137, states that the Community and the country members, having regard the social rights provided in the European social charter and the Charter of the Union for fundamental rights of employees, it is stated that their goal among other is improving living and working conditions,.... ${ }^{14}$ that is, improving, in particular, the working environment for health and safety protection". ${ }^{15}$

Article 118A of the Single European Act of 1986 states that "Member states oblige to promote improvement, especially in the field of working environment, protection and safety and health of employees, and achieving harmonization and progress with the existing conditions in this are."

\footnotetext{
${ }^{1416}$ See article 136 and 137 of the Contract on foundation of the European Community ${ }^{1517}$ Ibid
} 
In addition, article 11 of the ESP obliges contractual parties to take appropriate measures to eliminate, to a large extent, the causes of bad health, provide advisory and educational benefits for promotion of health and encouraging individual responsibility for health matters; as well as to prevent as much as possible epidemiological, endemic and other diseases, and also accidents.

\section{The Union Charter of}

fundamental social rights of the employees, adopted at the meeting of the Heads of states or governments of the EEZ Member States held in Strasbourg on 9 December 1989, also gives an important place to protection of health and safety at work. Article 19 of the Charter stipulates that "every employee must benefit in his own work environment from the satisfactory conditions of protection of his health and safety", i.e. to take "adequate protection measures, especially for involvement of employees from information and consulting on current risks and measures taken to overcome or reduce them.

Directive no. 83/391 of 16 June 1989, which is based on article 118A, regulates the general principles that produce a number of other recommendations in this area. This Framework Directive aims to improve the safety and health of employees at work. It establishes the general principles that are systematized in two types: action against risks (evaluation, elimination, prevention, adaptation to technical evolution), as well as general obligations of employers and employees in relation to health and safety at work.

Of the above legal instruments of the EU we can conclude that normatively this area is relatively well regulated which is a good basis for legal regulation of this problematic and at the national level of EU member states and candidate countries for EU membership.

\section{National regulation for safety} and health at work in the Republic of Macedonia

Very important element in the system of safety and health at work is the regulation. Elaborating on the importance of the abovementioned international legal instruments of the UN, ILO, EU in regulating the right of employees to safety and health at work, we can establish that our country RM, as a member of the UN, ILO and EU candidate country has ratified and accepted the most important international legal instruments (conventions, recommendations, charters, declarations) for safety and health at work. This means that RM has implemented the same in its own national labor legislative, which is basic precondition for out further integration in the international community, especially in the EU.

"Employees in the Republic of Macedonia exercise their right to a safe and healthy working environment with the employer in accordance with the Constitution of the Republic of Macedonia, the Law on Labor (Official Gazette of RM no. 62/05), the Law on Safety and Health at Work (Official Gazette of RM no. 92/07), and other laws from labor area, bylaw acts-rulebooks, as well as collective agreements." $" 16$

We mentioned above that the protection and safety and health of employees is a constitutional category. The Constitution of the Republic of Macedonia explicitly mentions the right to a healthy and safe working environment in article 32, where is stipulated that "Everyone has the right to work, free choice of employment, protection at work ....."17, and this right implies incorporation in its content not only rights but also obligations on the part of both the employee and the employer.

\footnotetext{
${ }^{16}$ Majhosev, A., \& Paraklieva, V. [2019]. Legal and institutional framework for safety and health at work in the Republic of North Macedonia. Journal of Process Management. New Technologies , 7(2), 44-53.

${ }^{17}$ See article 32 paragraph 1 of the Constitution of RM
} 
"The employer is obliged to provide protection during work of the employee, by providing the necessary conditions for such protection, pursuant to the Law on Labor (Official Gazette of RM no. 62/05).If the employer does not provide conditions for safety of life and health of employees, the law stipulates penalty provisions.

The employee is obliged to comply with the prescribed conditions and measures for work protection (article 32 of the Labor Law). In that context, the employee is obliged to perform the work in the workplace with care, in order to ensure not only his life and health, but also the life and health of other employees, as well as the citizens in general. If the employee does not comply with the prescribed measures for safety and health, or does not use the means and equipment for work protection according to the established regulations, by the Labor Law this is considered as violation of work discipline or non-fulfillment of obligations stipulated by law, collective agreement and an employment contract, due to which the employee is terminated the employment by dismissal from the employer without notice. This provision of the Law is undertaken in almost all special (branch) collective agreements, where certain specifics of the activity are preserved." 18

The Settlement on foundation of the Economic social council of the RM stipulates that "The Government of the Republic of Macedonia, the Federation of Trade Unions and the Economic Chamber of Macedonia, in order achieving the fundamental values of the Constitution of the Republic of Macedonia for democratic and social state and providing social justice for more harmonious development

\footnotetext{
${ }^{18}$ Majhosev, A., \& Paraklieva, V. [2019]. Legal and institutional framework for safety and health at work in the Republic of North Macedonia. Journal of Process Management. New Technologies , 7(2), 44-53.
}

of social processes, for the promotion of social dialogue, three-partism and the application of international conventions and recommendations, form the Economic and Social Council." "'The Council has an advisory-consultative function, through which the social dialogue takes place and a significant part of the negotiating function of the social partners for economic and social issues that are of interest to the RM." 20

"In accordance to these functions, the Council reviews issues and gives opinions, proposals and recommendations on certain issues in the field of working conditions and occupational safety." 21

\section{Law on Safety and health at work}

"Given the great importance of the Law on Safety and health at work (Official Gazette of RM no. 92/07) we believe that it is necessary to elaborate this law more widely. In fact, this law determines: 1) measures for safety and health at work; 2) general and other obligations of the employer; 3) rights and obligations of the employees in the field of safety and health at work; 4) preventive measures against occupational risks, elimination of risk factors for accidents; 5) informing and consulting the social partners about safety and health of the employees; 6) establishment and functioning of the Council for safety and health at work; 7) authorization; 8) supervision and 9) misdemeanor provisions.

The representative of the employees for safety and health also has an important place in the system of safety and health at work. The rights and obligations of the representative of the employees for safety and health at work are regulated by articles 28, 29 and 30.

\footnotetext{
${ }^{19}$ See article 1 of the Settlement of foundation of the Economic and Social Council in RM

${ }^{20}$ See article 3 of the Settlement of foundation of ESS

${ }^{21}$ See article 3 paragraph 2 of the Settlement of foundation of ESS in RM from 30.12.1996
} 
According to them, the representative of the employees for safety and health at work is elected by the employees from their rank, at a union meeting, or meeting of employees, taking into consideration the representation of all parts of the operational process and mandatory for those where the working conditions require (increased danger to the safety and health of workers, work in separate places, etc.). The employee representative enjoys special protection from employment, as does the representative of the trade union organization in the specific company, in accordance to the law and the collective agreement. The number of representatives depends on the number of employees, with: over 10 employees one representative is being elected; two representatives of 101-500 employees and three representatives of employers who have over 501 employees.

According the Law, the representative of the workers for safety and health at work has the right:

- to tour the workplaces in order to perceive the situation regarding occupational safety and health;

- to communicate to the employer about the needs and problems of safety and health at work;

- to inform the labor inspection and request its mediation or supervision;

- to inform the labor inspection about its possession, to attend, to give its observations and to have an insight in the minutes compiled by the inspectorate during mediation or supervision;

- request information from the employer and have access to occupational safety and health assessment statements;

- special training for prevention and safety and health at work, specific to the activity of the employer, which is determined by a collective agreement." 22

\section{Methodology for harmonization of national legislation with EU legislation}

Due to the success of the process of harmonization of the legislation of the Republic of Macedonia with the European law, for consistency, coordination and clear image and monitoring of the process of approximation of the legislation in 2000, the Methodology and structure for harmonization of the national legislation with the EU legislation was prepared.

"According to the Methodology, the harmonization process is divided into four stages: ${ }^{23}$

1. Preparatory phase - establishment of all necessary institutions for the implementation of the process, as well as activities of a technical nature, such as distribution and presentation of European legal acts in specific areas and presentation of the principles of harmonization in general.

2. Analytical phase - translation of the necessary European legal acts in Macedonian language and their incorporation in the Program for approximation of the national legislation to the European legislation in accordance with the previously defined priorities;

\footnotetext{
${ }^{22}$ Majhosev, A., \& Paraklieva, V. [2019]. Legal and institutional framework for safety and health at work in the Republic of North Macedonia. Journal of Process Management. New Technologies , 7(2), 44-53.

${ }^{23}$ Official site of the Assembly of the Republic of North Macedonia International cooperation. Last accessed on 07.01.2020

https://www.sobranie.mk/usoglasuvanje-nazakonodavstvoto.nspx
} 
3. Transposition phase - operational elaboration of new legislation in accordance with a previously defined plan. At this stage, the real approximation of the Macedonian legislation with that of the EU takes place. Namely, this is the stage where national experts and EU experts must prepare new draft laws or proposed amendments to existing laws or bylaws, in order to achieve compatibility between the legal order in the Republic of Macedonia and EU legislation and finally

4. Implementation phase - not only the adoption of new laws in the Assembly or amendments to existing ones, but also their proper implementation in practice and management of the effect they have on the existing institutional infrastructure."

The legal basis for adoption and harmonization of the legislation in the Republic of Macedonia is established based on the monistic approach, i.e. the supremacy of international law which is regulated in article 118 of the Constitution of the Republic of Macedonia (Official Gazette of RM no. 52/91, 1/92, 31/98, 91/2001) which states: "International agreements that are ratified in accordance to the constitution are part of the internal legal order and cannot be changed by law", i.e. Article 8, paragraph 1, line 10: "The fundamental value of the constitutional order of the Republic of Macedonia is ... (10) the observance of the generally accepted norms of international law".

The harmonization of the Macedonian legal system with the EU law is a complex process, which can be efficient and take place with the necessary speed if it respects certain methodological postulates such as:

1. Determination of the right goals, choosing the appropriate methods and priorities;
2. Determination of the appropriate phases and rigorous planning and conducting the harmonization process, as opposed to the dynamics of the development of the legal system;

3. Establishing effective application of harmonized regulations, not just formal compliance.

The harmonization process refers to the entire acquiscommunitaire which includes much more than legal regulations. The harmonization refers to 35 chapters $^{24}$

\section{Incorporation of European} legislation in the Law on Safety and Health at Work of the Republic of $N$. Macedonia

By application for membership of the Republic of North Macedonia in the European Union on March 22, 2004, begins the process of harmonization of domestic with European legislation, and thus inevitably harmonization of domestic legislation on safety and health at work with European. As a framework directive on occupational safety and health 89/391/EES (Council Directive of 12 June 1989), it inevitably followed that national legislation on occupational safety and health should be harmonized exactly according to principles of this directive.

24"1.Free movement of goods; 2.Free movement of employees; 3.Right of foundation and freedom of providing services; 4.Free movement of capital; 5.Public procurement; 6.Right of trade companies; 7.Intellectual property right; 8.Competition policy; 9.Financial services; 10.Information society and media; 11. Agriculture and rural development; 12.Food safety, veterinary and phytosanitary policy; 13.Fishery; 14.Transport policy; 15. Energetics; 16.Taxation; 17.Economic and monetary policy; 18.Statistics; 19.Social policy and employment; 20.Enterprises and industrial policy; 21.TransEuropean networks; 22.Regional policy and coordination of structural instruments; 23.Judiciary and fundamental rights; 24.Justice, freedom and security; 25.Science and research; 26.Education and culture; 27.Environment; 28.Consumer protection and health care; 29. Customs Union; 30.Foreign relations; 31.Foreign security and defense policy; 32.Financial control; 33.Financial and budgetary provisions; 34.Institutions and 35.Other issues Official site of the Assembly of the Republic of North Macedonia, International cooperation. "Last $\begin{array}{llr}\text { time accessed } & 07.01 .2020\end{array}$ https://www.sobranie.mk/usoglasuvanje-nazakonodavstvoto.nspx 
By beginning of the process of harmonization of the existing Macedonian Law on Occupational Safety (Official Gazette no. 13/98), which arose from the Constitution of the Republic of Macedonia, following article 32, with the Framework Directive on Occupational Safety and Health (89/391/EES) set a precedent for the entire area known as "Occupational Safety" to be renamed "Occupational Safety and Health". Namely, the experts who were involved in the process of harmonization of the legislation in the Republic of Macedonia with the one of the European Union, came to conclusion that the existing regulation does not correspond to the one required by the framework directive and decided to fully translate the directive and its adaptation into national law, which would not treated the field of occupational safety, but the field of occupational safety and health.

In order to improve the protection of safety and health at work, labor experts have undoubtedly asked for establishment of a new Law that will protect these principles. Thus, on 1 August 2007, the Law on Occupational Safety and Health ${ }^{25}$ was adopted, which was fully harmonized with Framework Directive 89/391/EES. The law was designed in order introducing measures and activities aimed at improving the safety and health of workers at work. "At the same time, the Legislator by this law defines the measures for safety and health at work, the obligations of the employer and the rights and obligations of the employees in the field of safety and health at work, as well as the preventive measures against occupational risks, elimination of risk factors for accident, information, consulting, training of

\footnotetext{
${ }^{25}$ Law on safety and Health at Work Revised version ("Official gazette of Republic of Macedonia", 92/07, 136/11, 23/13, 25/13, $137 / 13,164 / 13,158 / 14,15 / 15,129 / 15,192 / 15,30 / 15)$
}

workers and their representatives and their participation in the planning and undertaking of occupational safety and health measures." 26

Basic principle according the Law is "the principle of prevention of injuries at work, occupational diseases and workrelated diseases". The Law on Safety and Health at Work introduces for the first time the institute "risk assessment", which introduces a new approach in preventing activity for raising preventive approach in creating safe and healthy working conditions, all in order to protect the health of employees.

The provisions of this law are applied in all activities of the public and private sector, for all persons insured against injury at work or occupational diseases according the regulations for pension, disability and health insurance and for all other persons involved in the work processes. $^{27}$

The provisions of this law do not apply to the activities if this matter is regulated by a special regulation (armed forces, police, in some special activities of the protection and rescue forces) as well as to home assistance.

In order to implement the requirements related to occupational safety and health, arising from the Law on Occupational Safety and Health, it is necessary to conduct a comprehensive and constant education of both employers and employees, also to all other participants that have an impact on the decision making process in this area and spreading culture of work.

\footnotetext{
${ }^{26}$ Majhosev, A., \& Paraklieva, V. [2019]. Legal and institutional framework for safety and health at work in the Republic of North Macedonia. Journal of Process Management. New Technologies , 7(2), 44-53.

27 Velkovski, T. (2018), Occupational safety and health Macedonian Occupational Safety and Health Association Skopje, 9 .
} 
Pursuant to the Work Program of the Government of the Republic of Macedonia and the National Program for Harmonization of the Legislation of the Republic of Macedonia with the Legislation of the European Union, among other obligations, there is a need to harmonize the laws and bylaws regulating the field of safety and health at work. The legislation in this area refers to the Law on Occupational Safety and Health (Official Gazette of RM no. 92/07 of 24.07.2007), the Law on modification and amendment of the Occupational Safety and Health (Official Gazette of the Republic of Macedonia No. 136 of 03.10.2011) and a group of bylaws that overall organize, regulate and ensure safety and health at work ${ }^{26}$.

\section{CONCLUSION}

As a summary of the above, we can conclude that although legislation in the field of occupational safety and health follows all European and international regulations and constantly complies with them, still the biggest problem is the lack of implementation.

The analysis of the European Commission Progress Reports ${ }^{27}$ of the Republic of Macedonia, primarily Chapter 4.19 , also indicates that our country is committed to the process of harmonization of national labor legislation related to safety and health. However, the reports note the need to strengthen the capacity of the labor inspectorate and collective contracting and re-point out the situation of inadequate enforcement of protection regulations and the large number of workrelated injuries and deaths. For further harmonization with EU standards, it is necessary to have in consideration the directives of the European Agency for Safety and Health at Work (EU-OSHA).28
The EK Reports also emphasize that our legal system has successfully and almost completely transponder the law of the European legislation in the field of safety and health at work, but lacks proper, correct and precise implementation of the legal regulations, i.e. the state through the institutions insufficiently promotes the application of the practice of good legal solutions.

As a major remark in the reports is stated that the administrative capacity, still not sufficiently staffed and does not have adequate capacity for normal operation, is not adequate to ensure proper implementation and enforcement of legal provisions, as well as poor interinstitutional coordination and cooperation.

Nevertheless, according to EK Reports, as well as the Reports conducted by state and non-governmental organizations, there is no reduction in accidents at work, but they are constant, which indicates that not only harmonization of European legislation but also greater diligence is not enough and action by all concerned institutions, as well as employers in order to improve the protection of safety and health at work of workers. The EK has repeatedly noted in the Reports that better consolidation of accident data collection is needed.

According to above, we can conclude that the Republic of Northern Macedonia is a country that is moderately prepared for compliance with EU legislation in this area, i.e. if it should be assessed with a score from 1 to 5 , in the field of occupational safety and health, the same according to EU is scored with 3 . 


\section{REFERENCES}

1) Benjamin, Ali (2011), Basic principles of occupational safety and health, MZZPRSkopje;

2) Belovski, V and Majhoshev, A (2017), Labor law, University Goce DelchevShtip;

3) Velkovski, T. (2018), Safety and health at work, , MZZPR-Skopje;

4) Agreement for foundation of the European Union,

5) European social charter, European council;

6) Unique European act of 1986

7) Law on occupational safety and health Revised version ("Official gazette of Republic of Macedonia" 92/07, 136/11, 23/13, 137/13, 164/13, 158/14, 15/15, 129/15, 30/15);

8) Law on labor ("Official gazette of RM" no.62/05);

9) Reports on the progress of the Republic of Macedonia for the period 2006-2020);

10) International pact for economic, social and cultural rights of UN (1966);

11) Majhosev, A., \& Paraklieva, V. [2019]. Legal and institutional framework for safety and health at work in the Republic of North Macedonia. Journal of Process Management. New Technologies, 7(2), 44-53.

12) Methods of harmonization of the national legislation to the European Union law. (2008). Book-2, Macedonian Academy of Sciences and Arts, Skopje, 12.
13) National Program for the Adoption of the Approximation of EU Legislation. Approached on 01.12 .2020

https://www.mtsp.gov.mk/nacionalnaprograma-za-usvojuvanje-na-pravoto-naeu-npaa.nspx,

14) Official site of the assembly of the republic of north Macedonia, International cooperation. Last time approached on 07.01.2020,

https://www.sobranie.mk/usoglasuvanjena-zakonodavstvoto.nspx

15) Official site of the European Organization for Health and Safety at Work, accessed on: 05.12.2020 https://bit.ly/2GS9Hf3

16) Charter of the Association for the Fundamental Social Rights of employees, 1989

17) Universal declaration of Human rights (1948);

18) Constitution of ILO (International labor organization);

19) Constitution of RM

20) The Philadelphia Declaration of 10 of June 1944, ILO

21) Harmonization. Last approached on 01.12 .2020

https://ec.europa.eu/neighbourhoodenlargement/policy/conditionsmembership en .

22) White paper on the preparation of the Associated Countries of Central and Eastern Europe for Integration into the Internal Market of the Union. COM(95) 163 final. Executives summary Vol.Ipage 3-6 